\title{
PENINGKATAN KETERAMPILAN MOTORIK HALUS MELALUI KEGIATAN MELIPAT KERTAS PADA KELOMPOK B DI TK FLAMBOYAN TOLOWATA AMBALAWI
}

\author{
Vivi Rubianti, Sri Jamilah \\ Email: srijamilah49@gmail.com
}

\section{ABSTRAK}

Penelitian ini bertujuan untuk meningkatkan keterampilan motorik halus melalui origami pada anak kelompok B TK Flamboyan Tolowata Ambalawi Bima. Jenis penelitian ini adalah Penelitian Tindakan Kelas. Subjek penelitian adalah anak kelompok B yang berjumlah 19 anak terdiri dari 10 anak laki-laki dan 9 anak perempuan. Objek penelitian ini adalah keterampilan motorik halus. Metode pengumpulan data yang digunakan adalah observasi, dokumentasi, dan wawancara. Instrumen yang digunakan adalah pedoman observasi, dokumentasi dan wawancara. Teknik analisis data dilakukan secara deskriptif kuantitatif dan kualitatif. Indikator keberhasilan yang ditetapkan yaitu minimal $75 \%$ dari 19 anak memiliki keterampilan motorik halus dan kriteria baik. Penelitian ini dilaksanakan dalam dua siklus. Hasil penelitian menunjukkan bahwa keterampilan motorik halus anak meningkat setelah adanya tindakan melalui origami. Pada saat dilakukan observasi pratindakan, persentase keterampilan motorik halus anak sebesar 39,47 \%. Pada siklus I sebesar $50,86 \%$ dengan peningkatan 11,39\%. Pada siklus II sebesar 60,33\% dengan peningkatan 9,47 \%. Perolehan persentase tersebut menunjukkan bahwa keterampilan motorik halus anak kelompk B dengan kriteria baik telah mencapai indikator keberhasilan $75 \%$. Langkah-langkah yang ditempuh untuk meningkatkan keterampilan motorik halus anak adalah 1) guru menjelaskan cara melipat kertas dengan metode demonstrasi; 2) anak diberi penguatan dengan kata "setrika lipatan" yang sudah dibuat; 3 ) anak diberi reward berupa pujian; 4) penggunaan kertas lipat motif untuk memarik minat anak.

Kata Kunci: Keterampilan Motorik Halus, Anak Kelompok B, Origami 


\section{PENDAHULUAN}

Maraknya pemberitaan tentang kasus kekerasan seksual dan prilaku seks yang menyimpang, seperti seks abuse, dan free sex, menjadi ancaman bagi geerasi muda, khususnya anak-anak yang masih kosong dalam pengetahuannya tentang seks. Berdasarkan data KPAI (Komisi Perlindungan Anak Indonesia) kasus sexual abuse mengalami peningkatan dalam kurun 5 tahun terakhir.

Menurut data yang dihimpun dari KPAI pelaku kekerasan terhadap anak meningkat setiap tahunnya. Hasil pemantauan Komisioner KPAI data menunjukkan bahwa pihaknya menemukan 218 kasus kekerasan seksual anak pada tahun 2015. Sementara pada tahun 2016, KPAI mencatat terdapat 120 kasus kekerasan seksual terhadap anak-anak. Kemudian ditahun 2017, tercatat sebanyak 116 kasus. (kpai.go.id). Bahkan menurut Wakil Ketua Komisi Perlindungan Anak Indonesia (KPAI), Maria Advianti, melalui kpai.go.id (2015) menyatakan bahwa pelaku kejahatan seksual pada anak dapat dibagi menjadi tiga, yaitu orang tua, keluarga dekat, dan orang yang dekat di lingkungan rumah (kpai.go.id). Hal ini berarti anak yang seharusnya merasa aman dan terlindungi di lingkungan mereka sendiri, bersama orang-orang yang mereka kenal, justru menjadi korban oleh orang-orang dewasa yang dekat dengan mereka.

Menurut Sensus Penduduk tahun 2011, diperkirakan jumlah anak usia 6-17 tahun adalah 82,7 juta atau sekitar 33,9\% dari total seluruh penduduk Indonesia, dengan 51,3\% adalah anak perempuan dan 48,7\% adalah anak laki-laki. Berdasarkan Profil Anak Indonesia tahun 2012, $60 \%$ korban eksploitasi seksual adalah anak-anak, yang mayoritasnya adalah perempuan. Hampir di semua wilayah Indonesia ditemukan kasus eksploitasi komersial anak. Eksploitasi komersial adalah anak yang dilacurkan, pelacuran anak, perdagangan anak untuk tujuan seksual dan pornografi. Diperkirakan, 30\% dari total pekerja seks komersial di Indonesia adalah anak-anak. ${ }^{1}$

Berdasarkan Riskesdas 2010, umur pertama berhubungan seksual adalah 8 tahun, yang merupakan umur anak sekolah dasar. Saat ini,

${ }^{1}$ Yusuf, A. H, Yugiana, E, Nuryetty, M. T, Handiyatmo, D., Wajdi, N., Wirananggapattie, T. I. \& Saleh, A. M. Profil Anak Indonesia, Jakarta: Kerjasama Kementrian Pemberdayaan Perempuan \& PA dengan BPS, 2012.

Jurnal Pelang̉i Jurnal pemikiran dan penelitian pendidikan Islam anak Usia Dini 
berdasarkan laporan yang sama, rata-rata usia menarche (usia anak pertama kali mendapatkan menstruasi) adalah 12,4 tahun dengan 0,3\% nya terjadi di usia 9 tahun. Kelompok umur 10-14 tahun adalah kelompok terendah yang mendapatkan penyuluhan kesehatan, yaitu $13,7 \%$, dibandingkan dengan kelompok umur lainnya. ${ }^{2}$

BerdasarkandataBadanPemberdayaanPerempuandanPerlindungan Anak Kota Dumai, pada tahun 2012 terdapat 8 kasus kekerasan seksual pada anak. Di tahun 2013 dilaporkan meningkat menjadi 10 kasus, dan di awal tahun 2014 ini, telah dilaporkan 5 kasus kekerasan seksual pada anak. Hal yang lebih mengkhawatirkan adalah rentang usia anak yang menjadi korban kasus kekerasan seksual tersebut adalah di bawah 10 tahun. Jumlah kasus ini adalah kasus yang terlaporkan, mungkin yang tidak terlaporkan melebihi angka tersebut, mengingat tindak kekerasan seksual merupakan kasus yang cukup sensitif. Kesadaran masyarakat akan perlunya melaporkan kasus tersebut ke pihak yang berwenang masih sangat rendah. ${ }^{3}$

Adanya peningkatan kasus ini harus menjadi perhatian bersama. Orangtua, sekolah, pemerintah dan semua pihak haruslah menjadi pelindung anak dari berbagai hal, termasuk perlindungan terhadap penyimpangan seksual. Seringkali kasus kekerasan seksual dilakukan oleh orang-orang terdekat anak. Oleh karena itu, sudah sepatutnya anak memiliki bekal perlindungan diri yang cukup semenjak dini.

Fenomena kekerasan dan penyimpangan seksual yang menimpa anak-anak di lingkungan mereka sendiri disebabkan oleh beberapa faktor, salah satunya adalah kurangnya pendidikan seks pada anak dan masyarakat. Menurut Yuliana seorang pemerhati perempuan dan anak dari Komunitas Jejer Wadon Solo, menyatakan bahwa maraknya kasus kekerasan seksual terhadap perempuan dan anak dipicu karena masih rendahnya pemahaman pendidikan seks. Masyarakat terutama orangtua, menganggap bahwa pendidikan seks merupakan sesuatu yang tabu dan tidak layak untuk diberikan kepada anakanak mereka. Hal ini sejalan dengan pendapat Musdah Ketua Umum

${ }^{2}$ Elizar. Persepsi Remaja tentang Gaya Pengasuhan Orang Tua dengan Perilaku Seksual Remaja SMU di Kota Lhoksumawe. Thesis, Universitas Gadjah Mada, 2010, hal. 19.

${ }^{3}$ L Counterman \& D Kirkwood, Understanding Healthy Sexuality Development in Young Children. Pediatric Clinics of North America. hal.765-780. 
Indonesian Conference on Religion and Peace (ICRP), menyatakan bahwa Pendidikan seksual yang komprehensif adalah untuk mengajarkan menghargai dan mengapresiasi sesama manusia. ${ }^{4}$

Pendidikan seks yang diberikan sejak dini mampu mengurangi potensi resiko yang timbul akibat perilaku seksual, seperti kehamilan yang tidak direncanaka dan penularan penyakit seksual, sehingga membantu meningkatkan kualitas hubungan yang positif pada anak. Perlunya pendidikan seks bagi setiap individu tidak hanya untuk melidungi diri dari perilaku menyimpang seks, namun juga memberikan pemahaman kepada anak tentang batasan-batasan sebagai seorang lakilaki dan perempuan (Justicia, 2016). Akan tetapi, kenyataannya yang ada saat ini orangtua masih menganggap pendidkan seks merupakan hal tabu untuk disampaikan kepada anak. ${ }^{5}$

Rendahnya kesadaran orangtua dalam memberikan perlindungan kepada anak, menjadi salah satu faktor penyebab meningkatnya kasus penyimpangan seks, seperti sexual abuse. Dari hasil penelitian KPAI, 70\% orangtua belum mampu mengasuh anak mereka menggunakan metode yang sesuai dengan perkembangan zaman sekarang

Kebanyakan orangtua beranggapan bahwa pendidikan seks hanya berisi tentang pemberian informasi alat kelamin dan berbagai macam posisi dalam hubungan seks. Kesimpangsiuran tentang arti pendidikan seks yang sebenarnya, menjadikan masyarakat memiliki persepsi bahwa pendidikan seks terlalu vulgar apabila diberikan pada anak-anak. Masyarakat awam cenderung memiliki anggapan bahwa pengetahuan tentang seks adalah ranah untuk orang dewasa dan anak-anak akan mengerti dengan sendirinya saat mereka dewasa.

Rahmawati menjelaskan bahwa anak yang tidak menerima pendidikan seks memiliki risiko untuk melakukan perilaku seks yang negatif di masa mendatang (remaja). Hal tersebut dikarenakan anak mencari tahu pada sumber yang tidak tepat sehingga berpotensi mendapatkan pemahaman yang keliru tentang seks yang menyebabkan anak melakukan perilaku menyimpang.

${ }^{4}$ http:// solo.tribunnews.com/2016/05/23/marak kasus-kekerasan-seksual-jejer-wadonsolo-nilairespon-pemerintah-telat, diakses tanggal 3 Juni 2016, Pukul 21.00 WIB.

${ }^{5} \mathrm{R}$ Justicia, Program Underwear Rules untuk Mencegah Kekerasan Seksual Pada Anak Usia Dini, Jurnal Pendidikan Anak Usia Dini, (2016), Volume (2) Nomor.2, hal. 217-218.

Jurnal Pelang̉i Jurnal pemikiran dan penelitian pendidikan Islam anak Usia Dini 
Keluarga adalah unit terkecil dari masyarakat. Keluarga merupakan lingkungan utama dari seorang individu. Sejak seseorang lahir sampai datang masanya ia meninggalkan rumah untuk membentuk keluarga sendiri sebagai lingkungan primer, hubungan antar manusia yang paling intesif dan paling awal terjadi adalah keluarga. Keluarga memiliki akses yang tidak terbatas kepada seorang anak. Orangtua adalah agen bersosialisasi yang memiliki kekuatan yang sangat besar bagi seorang remaja. Orangtua memiliki posisi yang sangat kuat dalam mempertajam sikap dan perilaku serta menolong anak agar hidup sehat. Posisi orangtua yang kuat ini, memberikan pengaruh yang lebih besar dalam mempromosikan kesehatan reproduksi dibandingkan dengan sumber informasi lainnya.

Melalui perannya yang sangat besar, orangtua seharusnya menjadi rujukan utama seorang anak dalam berbagai hal, termasuk informasi kesehatan reproduksi yang tepat dan benar. Pembicaraan tentang topik kesehatan reproduksi tidak bisa dilakukan dalam sekali dialog, namun harus berkelanjutan. Kesempatan ini dipegang oleh orangtua. Pembicaraan tentang topik kesehatan reproduksi dilakukan sedini mungkin, berkesinambungan dan secara berturut-turut.

Berdasarkan penelitian Opara, melalui kuesioner kepada 158 orang wanita usia 30-49 tahun, sebanyak 80\% dari responden setuju bahwa anak-anak membutuhkan pendidikan seks, tetapi hanya $15 \%$ nya saja yang memiliki pengetahuan yang baik tentang pendidikan seks. Sebanyak 111 responden mengatakan setuju bahwa pendidikan seks adalah tanggung jawab orangtua untuk mengedukasi anaknya. Sebanyak $70 \%$ dari responden mengatakan bahwa rumah adalah tempat terbaik untuk pendidikan seks.

Menurut Elizar, peran orangtua dan keluarga merupakan bagian penting dari lingkungan sosial yang sangat dibutuhkan sebagai pusat perkembangan remaja menuju kematangan seksual. Hal ini sebagai upaya pencegahan perilaku seksual berisiko, sedangkan keterlibatan orangtua untuk pencegahan dan menjelaskan perilaku berisiko pada kesehatan sangat diperlukan. ${ }^{6}$

Mengawali pemberian pendidikan seks sesuai dengan usianya merupakan langkah yang baik. Pendidikan seks akan menolong anak

${ }^{6}$ Opara, $\mathrm{P}$, dkk, Mothers perception of sexuality education for children, Nigerian Journal of Medicine, 19(2), 2010, hal.18. 
memahami tubuhnya. Komunikasi yang terbuka sejak dini dan jujur akan membuatanakmerasa nyamanuntukmembicarakan banyakhal termasuk seks, depresi, hubungan dengan lawan jenis dan penyalahgunaan obat dan alkohol. Penelitian Fentahur, dkk, menunjukkan bahwa menurut guru dan siswa, usia untuk memperkenalkan pendidikan seks adalah 5 tahun, sedangkan menurut orangtua, usia untuk memperkenalkan pendidikan seks di sekolah adalah usia 7 tahun. Hal ini senada dengan hasil penelitian lainnya yang menunjukkan bahwa 6-10 tahun adalah usia ideal untuk memulai pendidikan seks. ${ }^{7}$

Pendidikan seks seharusnya menjadi bentuk kepedulian orang tua terhadap masa depan anak dalam menjaga apa yang telah menjadi kehormatannya, terlebih bagi seorang perempuan. Pendidikan seks menjadi penting mengingat banyaknya kasus-kasus yang terjadi mengenai tindak kekerasan seksual terhadap anak dan remaja. Tetapi yang terjadi di lapangan justru orang tua bersikap apatis dan tidak berperan aktif untuk memberikan pendidikan seks sejak usia dini kepada anaknya.

Peran orangtua dalam memberikan pengajaran tentang seks sangat penting, terutama ibu. Sebagaimana diketahui bahwa "al-ummu madrasah al-ula" ibu merupakan madrasah pertama bagi anak. Pengetahuan ibu tentang pendidikan seks memiliki pengaruh terhadap penerapan pendidikan seks kepada anak.

Dari hasil wawancara awal yang di lakukan terhadap tiga responden yang berkaitan dengan peran orang tua dalam memberikan pendidikan seks pada Anak Usia Dini,

Responden yang berinisialSV“ kalau saya sudah memberikan pendidikan seks pada anak saya.. menjelaskan batasan aurat pada anak saya mas, mana yang boleh dan tidak boleh diperlihatkan pada orang lain"

Pendidikan seks itu kan aib untuk anak-anak mas, jadi tidak boleh diajarkan pada anak nanti mereka akan penasaran dan justru ingin mencoba lagi, (RH)

"mereka kan masih kecil mas, belum tau apa-apa, jadi belum bisa diberikan pendidikan seks" (YN)

Dari ketiga responden tersebut yang sudah memberikan pendidikan tentang seks sejak dini, pada saat anak mulai bertanya tentang bagaimana

${ }^{7}$ Ibid,.......hal.19.

Jurnal Pelangi Jurnal pemikiran dan penelitian pendidikan Islam anak Usia Dini 
ibu bisa hamil, perbedaan, jenis kelamin antara laki-laki dan perempuan. Sedangkan keempat responden lainya beranggapan bahwa dengan memberikan pendidikan seks pada usia dini berdampak pada tingkat penasaran anak untuk mencoba, dan berpikir bahwa pengetahuan seks anak akan berjalan dengan sendirinya sesuai dengan perkembangan dan bertambahnya umur seorang anak.

Dari penemuan diatas mereka beranggapan bahwa pendidikan seks akan diperoleh anak seiring berjalannya usia ketika ia sudah dewasa nanti. Mereka seolah menyerahkan pendidikan seks kepada pihak sekolah sebagai sumber ilmu bagi anaknya. Padahal pendidikan seks sendiri belum diterapkan secara khusus dalam kurikulum sekolah. Pada saat ini banyak orang tua yang merasa jengah ketika anak-anaknya menanyakan tentang hal-hal yang berbau seksual, seperti mengapa ibu tidak sholat, mengapa ibu bisa hamil, mengapa penis adik berdiri jika pagi hari, apa yang disebut dengan suami istri, mengapa perempuan bisa menstruasi, hingga penjelasan tentang mimpi basah anaknya. Orang tua merasa hal itu teramat tabu untuk dijawab apalagi untuk diperbincangkan. Padahal, tanpa atau didampingi orang tua, anak-anak pasti merasa penasaran dan selalu ingin tahu hal-hal yang membuatnya penasaran. Pendapat beberapa orang tua yang menganggap bahwa pendidikan seks untuk anak anak adalah tabu, ternyata keliru. Pendidikan seks tidaklah sesempit yang diekspektasikan kebanyakan masyarakat, pendidikan seks sangatlah luas. Pendidikan seks erat kaitannya dengan cara mendidik anak di rumah maupun di sekolah. Menurut Suwaid ada beberapa cara mengarahkan kecenderungan seksual anak, diantaranya: 1) melatih anak meminta izin ketika masuk rumah atau kamar orang tua; 2) membiasakan anak menundukkan pandangan dan menutup aurat; 3) memisahkan tempat tidur anak; 4) melatih mandi wajib; 5) menjelaskan perbedaan jenis kelamin dan bahaya berzina. ${ }^{8}$

Padahal, beberapa riset menyimpulkan bahwa pendidikan dan diskusi tentang seks bersama orang tua dan guru akan berdampak positif bagi perkembangan anak.

Hasil riset yang dilakukan oleh Zelnik dan Kim (1982) menunjukkan

${ }^{8}$ Lestari, dkk, Identifikasi Kebutuhan Informasi Seksualitas Pada Remaja, Jurnal Ilmiah Psikologi, 5 (2), 2011, hal. 180-182. 
bahwa jika orang tua bersedia mendiskusikan seks dengan anaknya, maka anaknya cenderung menunda perilaku seksual premarital. Seharusnya orangtua sebagai madrasah pertama bagi anak sudah mempersiapkan diri untuk menghadapi pertanyaan anak seputaran seks, karna idealnya orangtua merupakan sumber informasi awal bagi seorang anak. Idealnya orang tua merupakan sumber informasi seksualitas yang paling penting karena selain menginformasikan fakta juga menyampaikan nilai. Namun sayangnya, akses remaja terhadap sumber informasi seksualitas yang dapat dipertanggung jawabkan masih terbatas. ${ }^{9}$

Sebenarnya orang tua masih menjadi variabel penting dalam pengambilan keputusan pada remaja terkait perilaku seksualnya. Pada umumnya orang tua beranggapan anak akan mengetahui sendiri tentang seks apabila mereka telah besar dan dewasa.

Berdasarkan anggapan tersebut orang tua akan cenderung menolak atau menghindar ketika anak ingin mendiskusikan tentang seks. Namun, orang tua kurang menyadari bahwa sikap tersebut justru mendorong remaja untuk mencari jawabannya pada sumber lain yang mudah diakses seperti teman dan internet karena rasa ingin tahu tentag seks akan tetap berkecamuk dalam pikiran mereka. Disisi lain, anak secara alamiah memiliki rasa ingin tahu terhadap masalah seksualitas.

Dengan memperhatikan minat pada seks dalam diri anak, maka pendidikan seksual sangat perlu diberikan kepada anak karena pendidikan seks yang bersumber dari orang tua lebih menjamin proses kesinambungan, berbeda dengan informasi seksualitas yang diperoleh dari luar yang seringkali tak dapat dipertanggungjawabkan kebenarannya dan mungkin anak hanya akan mendapatkan informasi secara parsial. ${ }^{10}$

Untuk itu perlunya peran orang dewasa atau orang terdekat anak, dalam hal ini yaitu orang tua agar dapat memberikan informasi mengenai pendidikan seks terhadap anak. Maka dalam hal ini diperlukan bekal orang tua untuk menjadi lebih terbuka serta

${ }^{9}$ Ibid,.......hal.190.

${ }^{10}$ Ilmawati, Zulia, Bagaimana Pendidikan Seks dalam Perspektif Islam? http://id.- theasianparent.com/ pendidikan-seks-dalam-perspektif-islam/, 12 Desember, 2017, diakses jam 10.30 WIB.

Jurnal Pelangỉ Jurnal pemikiran dan penelitian pendidikan Islam anak Usia Dini 
informatif terhadap anak khususnya mengenai pendidikan seksual agar dapat memberikan pendampingan yang baik bagi anak dan diharapkan anak terhindar dari perilaku penyimpangan seksual dan orangtua diharuskan mengajarkan anak tentang pendidikan seks sedini mungkin.

Dari penemuan diatas menunjukan bahwa betapa pentingnnya keterlibatan orang tua dalam memberikan pendidikan seksual sejak dini dalam lingkungan keluarga untuk memberikan informasi awal tentang seksual. Maka peneliti tertarik untuk meneliti tentang "Peran Orang Tua Dalam Pendidikan Seks Pada Anak Usia Dini".

\section{METODE PENELITIAN}

Penelitian ini mengunanakan penelitian kualitatif fenomenologis. Tehnik pemilihan informan menggunakan teknik "purposive sampling". Pengumpulan data dalam penelitian ini adalah wawancara dan dibantu dengan alat rekaman berupa "Handphone". Pedoman wawancara yang dipakai adalah pedoman wawancara semi terstruktur. Keabsahan data dalam penelitian ini dengan melakukan triangulasi data, yaitu mencocokkan data yang diperoleh dari beberapa sumber data. ${ }^{11}$ Penelitian ini dilakukan di Kabupaten Bima Nusa Tenggara Barat. Responden utama adalah orangtua yakni ayah dan ibu yang memiliki anak usia dini dengan karakteristik pasangan suami istri yang memiliki anak pertama dengan usia 3-5 tahun.

Pengumpulan data dilakukan dengan metode wawancara dimaksudkan untuk mengungkap peran orang tua dalam pendidikan seks bagi anak usia dini. Wawancara yang dilakukan adalah wawancara semi terstruktur, kemudian membuat transkrip. Wawancara semi terstruktur mengandung makna dimana peneliti tidak menggunakan pedoman wawancara yang telah tersusun secara sistematis dan lengkap untuk mengumpulkan data. Pedoman yang digunakan hanya garisgaris besar saja. Dalam wawancara ini peneliti belum mengetahui secara pasti data apa yang akan diperoleh, sehingga peneliti lebih banyak

\footnotetext{
${ }^{11}$ Creswell, Research Design, Penelitian Kualitatif, dan Desain Riset., (Yogyakarta: Pustaka Pelajar , 2015) Edisi Ketiga (Terjemahan), hal.35.
} 
mendengarkan apa yang diceritakan oleh responden. ${ }^{12}$

Teknik analisis data dalam penelitian ini mengacu pada analisis data model interaktif Miles dan Huberman sebagai berikut: (1) Metode pengumpulan data melalui wawancara. Hasil wawancara direkam dengan handphone/digital voice recorder, kemudian dibuat transkrip verbatim secara lengkap, dibuat dalam bentuk tabel matriks, dan dianalisis datanya. (2) Reduksi data. Data hasil wawancara yang telah dibuat transkripnya dikelompokkan dalam kategori-kategori yaitu mencakup peran dan materi pendidikan seks untuk anak usia dini. (3) Display data. Data hasil wawancara yang telah dibuat kategorinya kemudian dibuat display dan dideskripsikan untuk menggambarkan pemahaman orang tua terhadap pendidikan seks. (4) Verifikasi/ kesimpulan. Langkah terakhir adalah membuat pembahasan yang diperkuat dengan teori mengenai peran orang tua dalam pendidikan seks. Hasil pembahasan kemudian dibuat dalam kesimpulan. ${ }^{13}$

\section{HASIL PENELITIAN}

Adapun hasil penelitiannya adalah sebagai berikut;

\section{1) Pemahaman Orang tuaTerhadap Seks}

Keberhasilan kegiatan pembelajaran yang berkaitan dengan kualitas dan keterampilan. Orang tua merupakan pendidik sentral dalam pemberian pendidikan seks pada anak, maka pemahaman terhadap apa yang akan diajarkan menjadi faktor besar dalam penentu keberhasilan. Pemahaman orang tua dalam pendidikan seks adalah hubungan badan antara laki-laki dan perempuan

Seks terkait persoalan biologis dan fisik yaitu menjelaskan perbedaan jenis kelamin. Perbedaan jenis kelamin berarti menjelaskan tentang perbedaan alat kelamin antara laki-laki dan perempuan agar anak mengetahui dan mengenal dirinya. A pabila anak lebih mengenal tentang jenis kelaminnya sendiri dan fungsinya maka akan semakin tumbuh kesadaran dan tanggung jawabnya karena orang tua adalah mewakili jenis pria dan wanita. Pemahaman orang tua terhadap seks yang benar

\footnotetext{
${ }^{12}$ Sugiyono, Metode Penelitian Pendidikan, (Bandung: Alfabeta, 2011), hal.34.

${ }^{13}$ Ibid,.....hal.35.
} 
inilah yang akan mempercepat proses pendidikan selanjutnya. Menurut Adebola, Olukemi Grace and Adebola, Femi Barnabas tahun 2015, menunjukkan bahwa perilaku seksual anak dipengaruhi oleh keluarga atau kehidupan seksual orang tua mereka, pendapatan, pendampingan dan tingkat pendidikan. ${ }^{14}$ Peran kedua orang tua sangat penting sekali dalam mendidik dan mengajarkan pendidikan seks anak usia dini. Lebih baik orang tua menerima pertanyaan seks dari anak sendiri dari pada anak sendiri menanyakan kepada orang lain karena belum tentu jawabannya itu baik dan benar bagi anak. Orang tua adalah orang yang pertama dan utama yang mengenalkan pendidikan seks kepada anak usia dini di lingkungan rumah sebelum orang lain yang mengenalkannya karena orang tua sebagai orang yang terdekat dengan anak dan orang yang paling mempengaruhi perkembangan dan masa depan anak. ${ }^{15}$

\section{2) Peran Orang Tua}

Pendidikan seks dimulai dari orang tua karena orang tua merupakan pendidik seksualitas utama. Dengan kesadaran ini maka rumah menjadi sumber kesinambungan dalam pendidikan seks. Orang tua harus memiliki kerjasama yang baik dalam pencapaian pendidikan seks.

\section{3) Menjelaskan Perbedaan Jenis Kelamin}

Menurut Hungu tahun 2007 jenis kelamin adalah perbedaan antara perempuan dengan laki-laki secara biologis sejak seseorang lahir. ${ }^{16}$ Seks berkaitan dengan tubuh laki-laki dan perempuan, dimana laki-laki memproduksikan sperma, sementara perempuan menghasilkan sel telur dan secara biologis mampu untuk menstruasi, hamil dan menyusui. Perbedaan biologis dan fungsi biologis laki-laki dan perempuan tidak dapat dipertukarkan diantara keduanya, dan fungsinya tetap dengan laki-laki dan perempuan pada segala ras yang ada di muka bumi. Secara umum seks digunakan untuk mengidentiikasi perbedaan laki-laki dan perempuan dari segi anatomi biologis, sedang gender lebih banyak berkonsentrasi kepada aspek sosial, budaya, dan aspek aspek non

14Adebola, Olukemi Grace1 and Adebola, Femi Barnabas, Family characteristics: Indices of adolescents'sexual behaviour International Journal of Science and Technology Educational Research Vol. 6, No 2, hal.19.

15Fahmi, Pendidikan seks anak usia dini di lingkungan keluarga: Jurnal Qathrunâ Vol. 3 No. 2, 2016, hal.16.

16Hungu, Demograi Kesehatan Indonesia, (Jakarta: Penerbit: grasindo, 2007), hal. 35. 
biologis lainnya. ${ }^{17}$

\section{4) Menutup Aurat}

Mengajarkan batasan aurat pada anak sejak dini adalah mengedukasi bagaimana anak belajar bertanggung jawab atas dirinya, menjaga bagian tubuh mana yang tidak boleh disentuh dan diperlihatkan kepada orang lain yang bukan muhrim. Pada agama Islam ada bagian tubuh yang tidak boleh ditampakkan kepada orang lain, disebut aurat. Menurut Shobron tahun 2015 aurat adalah perkataan Arab 'awrah, yang oleh Al-Tsa'libi dalam kitabnya yang berjudul Figh al-Lughah dijelaskan bahwa aurat adalah segala sesuatu yang memalukan karena terbukanya. Maka segala sesuatu yang membuat orang malu untuk membukanya di hadapan orang lain adalah aurat. ${ }^{18}$

Pada perempuan batasannya adalah wajah dan telapak tangan, sedangkan pada laki-laki mulai pusar sampai lutut sesuai dengan hadits riwayat Abu Daud, dari Aisyah r.a dia berkata;

"Bahwa Asma' binti Abu Bakar masuk ke ruang Rasulullah Shallallahu 'alaihi wasallam, sementara pakaian yang dikenakan tipis, maka Rasulullah Shallallahu 'alaihi wasallam berpaling darinya seraya bersabda kepadanya: Hai Asma', Sesungguhnya seorang perempuan apabila telah cukup umur(sudah sampai datang bulan), tidak pantas terlihat tubuhnya kecuali ini dan ini, seraya beliau menunjuk kepada muka dan telapak tangannya." Sedangkan pada laki-laki batasannya adalah pusar hingga lutut. Hal ini sesuai dengan hadits riwayat Ahmad dan Al Baihaqi "karena diantara pusar sampai lutut adalah aurat" ${ }^{19}$

\section{5) Toilet Training (Pelatihan Toilet)}

Toilet training pada dasarnya merupakan cara melatih anak untuk mengontrol kebiasaan membuang hajatnya di tempat yang semestinya, sehingga tidak sembarang membuang hajatnya. Toilet training bertujuan melatih anak untuk mampu BAK dan BAB di tempat yang telah ditentukan danjuga melatih anak untuk dapat membersihkan kotorannya sendiri serta memakai kembali celananya. Melihat hal tersebut, maka pelaksanaan toilet training merupakan waktu yang sangat tepat untuk

\footnotetext{
${ }^{17} \mathrm{Ibid}, \ldots . .$. hal.36.

${ }^{18}$ Shobron, dkk. Etika dan Mode Berpakaian Menurut Syariat I slam. (Surakarta : LPIK., 2015),hal.

${ }^{19} \mathrm{Ibid}$, .......hal.21.
} 20.

Jurnal Pelangi Jurnal pemikiran dan penelitian pendidikan Islam anak Usia Dini 
melakukan pendidikan seks kepada anak dengan cara memperkenalkan kepada anak tentang alat-alat reproduksi pada dirinya serta perbedaan jenis kelamin antara dirinya dengan temannya.

Tahap ini adalah tahap paling awal dalam pendidikan seks pada anak. Sambil dicebokin, anak dikenalkan dengan organ paling berharga yang tidak boleh disentuh orang lain. Jika ada yang menyentuhnya ajarkan anak untuk berteriak atau mengatakan kata Jangan atau Tidak boleh, dan mengadukannya kepada orang tuanya. Hal ini dilakukan sebagai bentuk pelatihan untuk melindungi diri anak sendiri, karena terkadang pelecehan seksual justru terjadi dari orang-orang terdekat seperti saudara, sepupu, paman, baby sitter, dan lain-lain. ${ }^{20}$

Toilet training adalah salah satu metode yang dapat meningkatkan keterampilan dan pemahaman anak dalam mengenali pendidikan seks, seputar pengenalan jenis kelamin dan alat reproduksi yang masih rendah dengan menerapkan strategi pengenalan secara langsung. Sebagaimana dikemukakan oleh Suherman tahun 2000 bahwa Toilet Training merupakan latihan moral yang pertama kali diterima anak dan sangat berpengaruh pada perkembangan moral anak selanjutnya. ${ }^{21}$

\section{KESIMPULAN}

Pemahaman orang tua terhadap seks adalah hubungan badan antara laki-laki dan perempuan, seks adalah sesuatu aib untuk dibicarakan kepada orang lain. Pendidikan orang tua sebagian berdasarkan pada pengalaman yang mereka alami, yaitu berdasarkan penggalaman yang didapatkan dari orang tua mereka dahulu.

Peran orang tua dalam pendidikan seks adalah mencakup menjelaskan perbedaan jenis kelamin laki-laki dan perempuan (2) mengedukasi anak untuk menutup aurat (3) mengenalkan penggunaan toilet. Orang tua menjelaskan kepada anak perbedaan jenis kelamin antara laki-laki dan perempuan dimulai dari bentuk tubuh, alat kelamin, gaya potongan rambut. Orang tua juga membiasakan anak untuk menutup aurat dimana anak dianjurkan untuk menggunakan pakaian

\footnotetext{
${ }^{20}$ Sarwono, S. W, Psikologi Remaja, (Jakarta: Grafindo Persada, 2002), hal.42.

${ }^{21}$ Suherman, Buku Saku Perkembangan Anak. (Jakarta: Penerbit EGC, 2000), hal.23.
} 
lengkap ketika bermain didalam maupun diluar rumah serta menjelaskan batasan aurat laki-laki dan perempuan, dimana batasan aurat laki-laki mulai dari pusar sampai lutut, sedangkan perempuan dimulai dari kepala sampai kaki kecuali muka dan telapak tangan. Selanjutnya orang tua mengenalkan penggunaan toilet kepada anak, dimana orang tua mengedukasi anak untuk terbiasa ketika BAB atau BAK harus di toilet dan mengajarkan anak untuk membersihkan alat kelaminnya.

\section{REFERENSI}

Adebola, Olukemi Grace1 and Adebola, Femi Barnabas, Family characteristics: Indices of adolescents' sexual behaviour International Journal of Science and Technology Educational Research Vol. 6, Nomor. 2.

Counterman L \& Kirkwood D, Understanding Healthy Sexuality Development in Young Children. Pediatric Clinics of North America., Vol.2, Nomor.3.

Creswell, 2015, Research Design, Penelitian Kualitatif, dan Desain Riset, Yogyakarta: Pustaka Pelajar, Edisi Ketiga (Terjemahan).

Elizar. 2010, Persepsi Remaja tentang Gaya Pengasuhan Orang Tua dengan Perilaku Seksual Remaja SMU di Kota Lhoksumawe. Thesis, Universitas Gadjah Mada.

Fahmi, 2016, Pendidikan seks anak usia dini di lingkungan keluarga, Jurnal Qathrunâ Vol. 3 No. 2.

Http://Solo.Tribunnews.Com/2016/05/23/Marak kasus-kekerasan-seksualjejer- wadonsolo- nilai- respon-pemerintah-telat, diakses tanggal 3 Juni 2016, Pukul 21.00 WIB.

Hungu, 2007, Demograi Kesehatan Indonesia, Jakarta: Penerbit: Grafindo. Ilmawati, Zulia, Bagaimana Pendidikan Seks dalam Perspektif Islam? http:// id.- theasianparent.com/pendidikan-seks- dalam-perspektif-islam/,12 Desember, 2017, diakses jam 10.30 WIB.

Justicia R, 2016, Program Underwear Rules untuk Mencegah Kekerasan Seksual Pada Anak Usia Dini, Jurnal Pendidikan Anak Usia Dini, Volume.2, Nomor 1.

Lestari, dkk, 2011, Identifikasi Kebutuhan Informasi Seksualitas Pada Remaja, Jurnal Ilmiah Psikologi, Vol.5, Nomor.2.

Jurnal Pelangi Jurnal pemikiran dan penelitian pendidikan Islam anak Usia Dini 
P Opara, , dkk, 2010, Mothers perception of sexuality education for children, Nigerian Journal of Medicine, 19 Vol.2, Nomor.2.

W S Sarwono, 2002, Psikologi Remaja, Jakarta: Grafindo Persada.

Shobron, dkk, 2015, Etika dan Mode Berpakaian Menurut Syariat Islam, Surakarta : LPIK.

Suherman, 2000, Buku Saku Perkembangan Anak, Jakarta: Penerbit EGC.

Yusuf, A.H, Yugiana, E, Nuryetty, M. T., Handiyatmo, D. Wajdi, N, Wirananggapattie, T. I. \& Saleh, A. M. Profil Anak Indonesia, 2012, Jakarta: Kerjasama Kementrian Pemberdayaan Perempuan \& PA dengan BPS. 